\begin{tabular}{|l|l|l|l|l|l|}
\hline MUNIBE Antropologia-Arkeologia & $n^{0} 72$ & $5-17$ & DONOSTIA & 2021 & ISSN 1132-2217 • eISSN 2172-4555 \\
\hline
\end{tabular}

\title{
Functional analysis of Middle Palaeolithic flint tools through experimental use wear analysis: the case of Prado Vargas (Cornejo) and Fuente Mudarra (Atapuerca), northern Spain
}

\author{
Análisis funcional de herramientas líticas del Paleolítico medio a través \\ del análisis de huellas de uso experimentales: el caso de Prado Vargas \\ (Cornejo) y Fuente Mudarra (Atapuerca), norte de España
}

KEY WORDS: Traceology, Experimental archaeology, Confocal microscope, Mousterian.

PALABRAS CLAVES: Traceología, Arqueología experimental, Microscopio confocal, Musteriense.

GAKO-HITZAK: Trazeologia, Arkeologia esperimentala, Mikroskopio konfokala, Mousteriarra.

Claudia SANTAMARÍA CABORNERO ${ }^{(1)^{*}}$, Marta NAVAZO RUIZ(2), Alfonso BENITO-CALVO(3)

\begin{abstract}
There are functional differences related to the peculiarities of each settlement. The material used to manufacture tools is one of the key factors in the analysis of use-wear traces in traceological studies. An experiment was conducted to test the development of these functional traces in two types of flints found at two Middle Palaeolithic settlements: Neogene flint, from the Fuente Mudarra open-air site Sierra de Atapuerca, and Cretaceous flint, from the Prado Vargas cave site, Ojo Guareña. After reviewing the characteristic of each type of flint, they were compared to previous archaeological studies in order to check the reliability of the analysis of these settlements.
\end{abstract}

\section{RESUMEN}

Existen diferencias funcionales en lo referente a las características de cada yacimiento. El tipo de material sobre el que están realizadas las herramientas líticas es una de las razones que condiciona la aparición de huellas de uso diagnósticas para estudios traceológicos. Se ha llevado a cabo un programa experimental para comprobar el desarrollo de estas huellas en dos tipos de sílex diferentes presentes en dos yacimientos del Paleolítico Medio de la provincia de Burgos: sílex neógeno, del yacimiento al aire libre de Fuente Mudarra en la Sierra de Atapuerca, y sílex cretácico, del yacimiento en cueva de Prado Vargas, Ojo Guareña. Una vez revisadas las características de cada sílex, se han contrastado con previos estudios arqueológicos para comprobar la viabilidad del análisis en estos yacimientos.

\section{LABURPENA}

Ezberdintasun funtzionalak daude aztarnategi ezberdinen ezaugarrien artean. Tresna litikoak egiteko erabilitako materialek, beste faktore batzuen artean, baldintzatu egiten dute azterketa trazeologikoetan diagnostikorako erabili ahal izateko aztarnak agertzea. Programa esperimental bat egin dute Burgoseko probintziako Erdi Paleolitoko bi aztarnategitan topa daitezkeen bi silex mota ezberdinetan aztarna horiek izandako garapena aztertzeko: silex neogenoan, Atapuercako mendilerroko Fuente Mudarra aire zabaleko aztarnategian; eta Kretazikoko silexean, Ojo Guareñako Prado Vargas kobazuloko aztarnategian. Silex bakoitzaren ezaugarriak aztertu ondoren, aurretiazko ikerketa arkeologikoekin kontrastatu dira, aztarnategi horietako analisiaren bideragarritasuna egiaztatzeko.

\section{INTRODUCTION}

Experimentation is widely used in archaeology investigation and it has considerable influence within traceology research. While Experiments differ in their content and aim, they allow us the identification and verification of the activity and economy of prehistoric groups.

Traceological analysis is an essential aid for understanding the use of prehistoric tools. Artefact func- tionality has always been one of the main issues in the study of archaeological sites, approached from a variety of disciplines such as ethnology and typological comparison (Calvo, 2002). Traceology involves the analysis of microscopic use-wear traces left on a tool (Martin, 2008). It allows researchers to compare the tool's use or non-use, the kind of materials seized and even the way the tool was used.

\footnotetext{
(1) Universidad de Burgos. Facultad de Humanidades y Comunicación. Dpto. De Historia, Geografía y Comunicación. Paseo Comendadores s/n. 09001 Burgos, España. *Corresponding author. E-mail: Csc0019@alu.ubu.es

(2) Universidad de Burgos. Facultad de Humanidades y Comunicación. Dpto. De Historia, Geografía y Comunicación. Área de prehistoria. Paseo Comendadores s/n. 09001 Burgos, España.

(3) Centro Nacional de Investigación sobre la Evolución Humana (CENIEH), Paseo Sierra de Atapuerca 3, 09002, Burgos, España.
} 
The observation of use-wear traces in isolation does not provide much information without previous documentation or an understanding of the process. Experimental replication in combination with ethnography are an indispensable tool for contrasting data. There are two essential experimentation methods, depending on the control of the variables: replicative and analytic (Cueto, 2012).

Traceological studies of Middle Palaeolithic settlements illustrate the difficulty of defining a general trend in the differentiated use of each morphotype. The presence of levels at sites with a functional orientation in terms of the typology or morphology of the tools has been documented: large-sized scrapers found on Level $\mathrm{D}$ at the La Combette site record the existence of transversal use on hide, whereas the smaller tools show greater variability in their use (Texier et al., 2003). Variable usage has been observed at most of the studied settlements, regardless of the morphotypes: in the older Quesem Cave (420-200 k.a.), Quina and Demi Quina scrapers were found with multipurpose usage on several materials, including both transversal and longitudinal movements (Lemorini et al., 2016) This suggests a functional trend which could also be differentiated by levels. There is no evidence of specialisation in the use of lithic tools within Mousterian variability.

The studies of Mousterian typology of Bordes (1961) that proposed the interpretation of different "facies" caused by cultural differences indicated by variation in the proportion of tools founded on macromorphological criteria. He came up with different interpretations as seasonal patterns of living, adaptation to the environment, or different groups with different ways of tool production (Bordes, 1961).

Other authors had added several interpretations. Binford will observe a functional relation where the activities performed result in the main difference of the tools (Binford and Binford, 1966). Dibble (1987) will defend that the characteristics of the raw material are conditioning the morphology of the tool. Rolland (1990) will see two conditions: the raw material and the type of activities carried out, and will say that they are dependent on the weather. Both authors will collided and offered a new explanation saying that the variation of the source material and the intensity of the occupation of the site (artefact-reduction intensity), are all induced by environmental factors (Dibble and Rolland, 1990). There are others (Kuhn, 1991) (Mellars 1992) (Monnier \& Missal, 2014), who contributed to the debate. Mousterian variability is not a closed topic nowadays.

This paper contributes to the debate on functionality with a study of material from two Middle Palaeolithic sites, Prado Vargas and Fuente Mudarra. The former is a cave occupation around 46.2 k.a. (Navazo \& Díez, 2008), while the latter is an open-air site, with a chronology between 123 to 45 ka. k.a. (Santamaría et al. 2020) whose lithic industry is largely flint.
In this paper an experiment was conducted to reproduce some of the main activities (meat processing, hide, bone, and wood scraping) of the hunter-gatherer groups at Fuente Mudarra and Prado Vargas (Figure 1), in order to compare the variables needed to produce use-wear traces on two kinds of flint, selected to generate a small reference collection and then compare it to a selection of archaeological sample.

The most frequent material at both sites is flint, Neogene in the case of Fuente Mudarra (Navazo et al. 2008, 2017) and Cretaceous in the case of Prado Vargas (Navazo et al., 2005, Vallejo et al., 2017). These two kinds of samples were analysed to find differences in the formation of use wear traces. We aim to see if there is a possible differentiation in their interpretation regarding the same activities between both types of flint, and if possible apply it to the archaeological comparisons.

\section{STUDY AREA}

Prado Vargas is a cave settlement in the Ojo Guareña karst complex (Cornejo, Burgos, Spain, Figure 1). It is part of the southern slope of the Cantabrian Range, in the north of the Iberian Peninsula. It is an old spring, occupied by both humans and animals (Navazo et al., 2005).

Archaeological excavations were conducted in 1986 and 2006 as part of a research project studying the cave in its entirety. The cavity was opened in 2016 to enlarge the cave floor and a mechanical probe has been carried out to know the $9 \mathrm{~m}$ stratigraphic sequence which contains several archaeological levels with an Upper Pleistocene-related chronology. The cave is 2-3 metres tall and is divided into three sections: a $30 \mathrm{~m} 2$ area near the mouth, a short corridor and the final area, 50 metres long (Navazo et al., 2005).

In 1986, four test pits were opened: A-D, the largest, $\mathrm{N}$ and $\mathrm{T}$, and finally a, nearest to the cave wall ( $\mathrm{Na}-$ vazo \& Díez, 2008). The excavation surface area was enlarged in the latter as it contained the only archaeological level defined then. Recent studies on the cave tells us that it is 9 metres deep from the bedrock to the top levels, and contains nine stratigraphic levels (Figure 1 ) in which we found archaeological remains in four of them: L2, L4, L8 and L9. The present paper focuses on Level 4 of the sequence (Figure 1, Unit 4) which is dated at 46.2 k.a. (Navazo \& Díez, 2008).

The faunal remains found in this settlement, Cervus elaphus, Equus ferus, Bos/Bison, Capra pyrenaica, Rupicapra pyrenaica, Sus scrofa, Oryctolagus sp., Ursus espelaeus, Canis lupus, Meles meles. Panthera pardus, Rhinocerotidae indet, Capreolus capreolus and Vulpes vulpes, were primarily herbivores, followed by carnivores and lagomorphs. The assemblage was heavily fragmented. (Navazo et al., 2005; Torres, 1989; Arceredillo, 2010) (Alonso-García et al. 2020) (De la Fuente et al. 2020). 


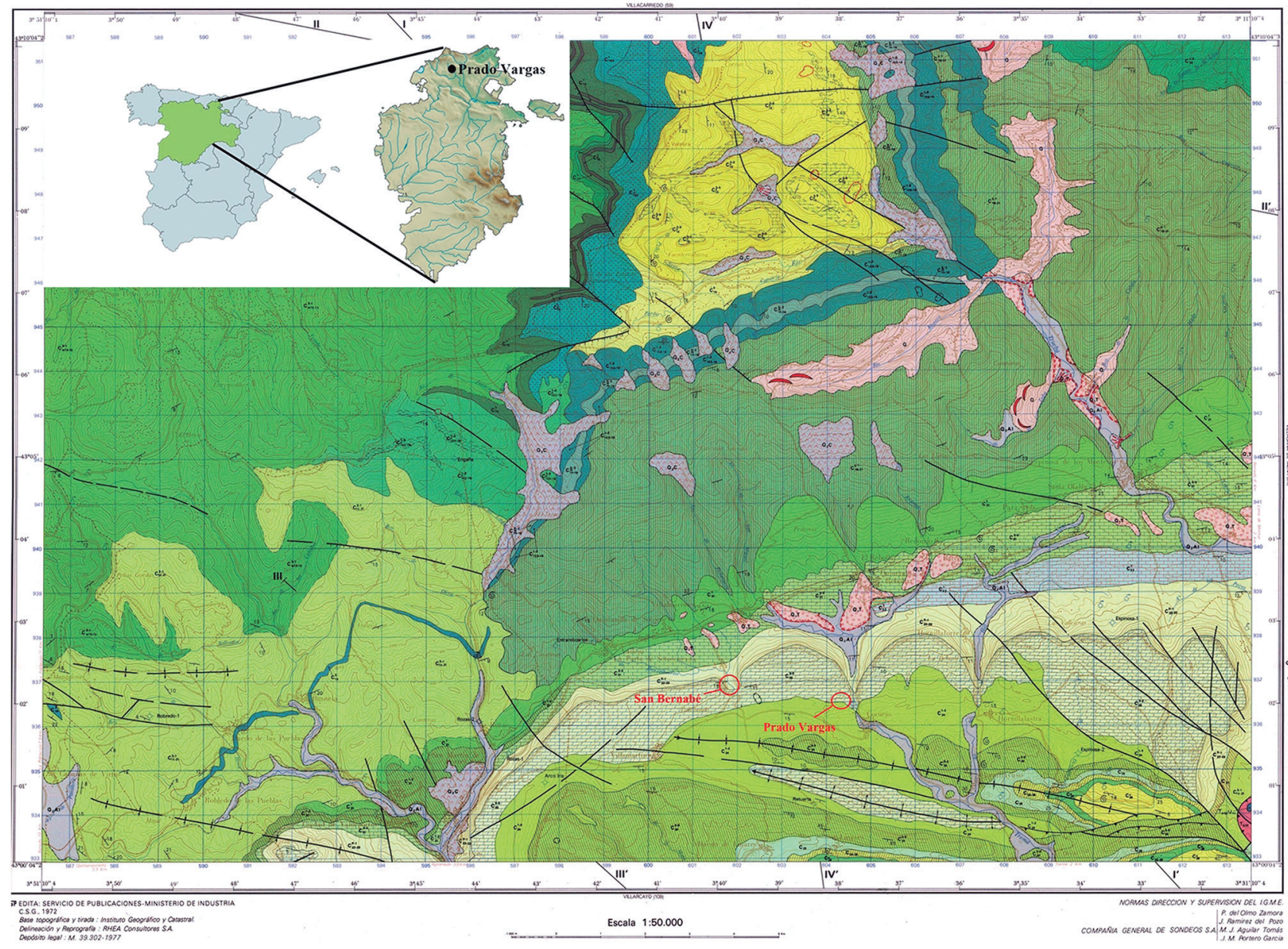

PV2018: NORTH SECTION X201

$\begin{array}{llll}100 & 101 & 102 & 103\end{array}$

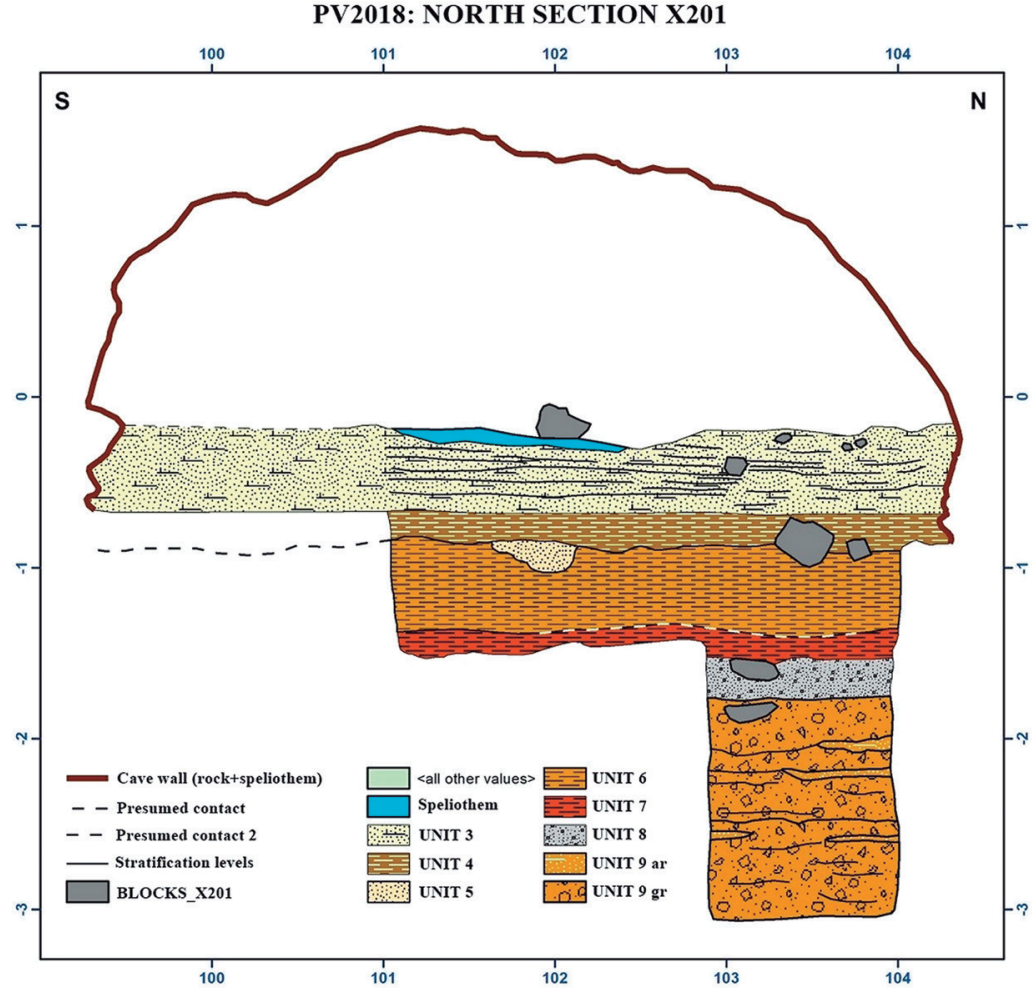

Fig.1. Villarcayo geological map, detail of the Prado Vargas site and San Bernabé (Information obtained from IGME): and Upper Palaeolithic stratigraphy Prado Vargas cave site, Cornejo, Spain. / Mapa geológico de Villarcayo detalle del yacimiento de Prado Vargas y San Bernabe (Información obtenida del IGME); y estratigrafía del yacimiento paleolítico de Prado Vargas, en Cornejo, España. 

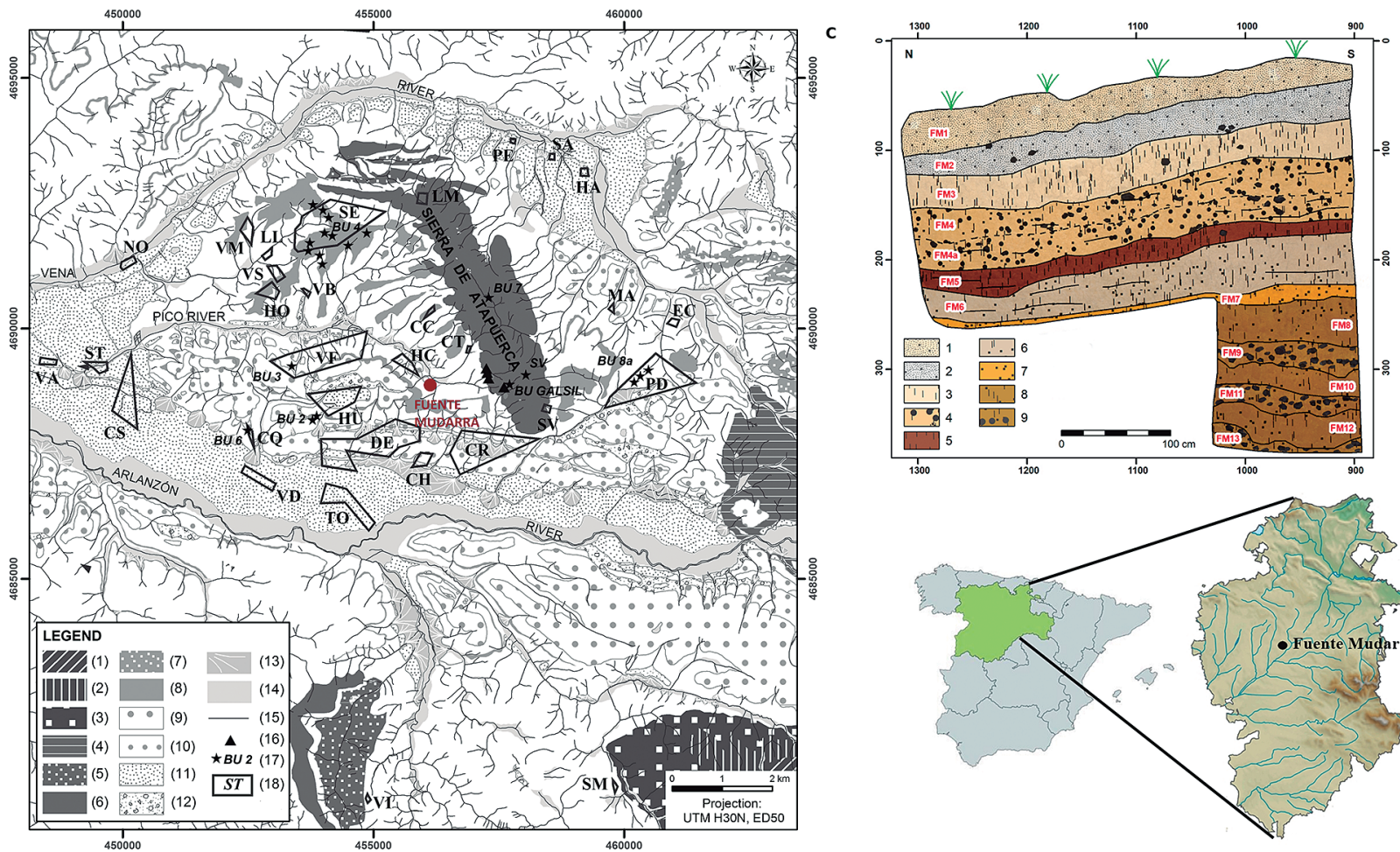

Fig.2. Geomorphological map of la Sierra de Atapuerca detail of Fuente Mudarra's site (Information obtained from Navazo and Carbonell, 2014): and Middle Palaeolithic stratigraphy of Fuente Mudarra open air site, Atapuerca, Burgos./ Mapa geomorfológico de la sierra de Atapuerca, detalle del yacimiento de Fuente Mudarra (información obtenida de Navazo y Carbonell, 2014); y estratigrafía del yacimiento al aire libre de Paleolítico medio de Fuente Mudarra, Atapuerca, Burgos.

The lithic complex at Level 4 is well-preserved, with no evidence of rounding, although patinas were common. The items recovered are mostly flakes (over $70 \%$ ), retouched flakes (around 10\%), and cores (around 7\%), but few natural bases and fragments (approx. 4-5\% each). The tool use was linked to skeletal remains bearing cut marks found at the site, whose most usable parts were previously selected outside the cave (Navazo et al., 2005).

This assemblage generally involved discoidal exploitation, aimed at removing small flakes and microliths (Bagolini, 1968). The cores were almost exhausted, and the final products were micro-sized removals. A large proportion was burnt. The most outstanding feature of Prado Vargas, however, was the large percentage (over $50 \%$ ) of cores recycled for use as tools.

The exploitation systems were predominantly discoidal, aimed at manufacturing flakes. Many of the flakes were plunging, broad, with some pseudo-Levallois points and Levallois flakes. As with the cores, no cortex was found on either the butts or the dorsal faces of the flakes.

Retouched flakes, slightly larger, followed the same pattern. Detected retouches were simple, denticulated and continuous. Tools were primarily notches and denticulates, followed by sidescrapers in a 60/40 ratio.

Fuente Mudarra is an open-air site in the Burgos Province, in this case in the Pico River valley, near the Sierra de Atapuerca sites (Figure 2). The Middle Pa- laeolithic chronology of Level 4, has been defined by OSL with a result of $56.831 \pm 3.31$ (Santamaría et al. 2020). It is part of a larger study of Neanderthal settlement patterns in the same mountain range (Navazo \& Carbonell, 2014; Navazo et al. 2017).

A $12 \mathrm{~m}^{2}$ test pit dug in 2012 (Santamaría and Navazo, 2016) revealed 13 levels, at least nine of which contained evidence of occupation: Levels 1, 2, 3, 4, 5, 7, 8, 9 and 10 (Figure 2) (Santamaría et al. 2020). Lithic material in almost the entire sequence is the only remains preserved, without any faunal evidence (Santamaría et al. 2020).

On Level 4, 1394 lithic items were recovered. This archaeological material was heavily degraded due to the formation of patinas, gelifraction scars and fracturing. There were also natural fragments of flint (several with gelifraction scars) as well as debris resulting from gelifraction in some of these natural fragments (Santamaría et al. 2020).

Neogene flint was the predominant raw material fond on Level 4 (89.31\% of items) (Santamaría et al. 2020), a preference due to the site lying on a secondary deposit of this material. Natural Neogene flint blocks were found that had been tested and used, with centripetal secant plane exploitations to produce small BPs, well-represented on this level (Santamaría et al. 2020).

Retouched tools only comprised $2 \%$ of the material on Level 4. Despite this modest representation, 
the types of BN2Gc were varied, and included sidescrapers, denticulates, notches, tayac points, becs and abrupts (Santamaría et al. 2020).

\section{MATERIAL AND METHODS}

The authors designed a controlled experimental protocol in which Neogene (Fuente Mudarra) and Cretaceous (Prado Vargas) flint samples were collected and knapped by experts. A total of 20 pieces of the two flint types were first scrutinised microscopically for differences in knapping and/or accidental marks, and then again under a binocular magnifying glass and a confocal microscope.

\subsection{Sample Collection and Knapping}

In the case of Fuente Mudarra, the authors collected samples of Neogene flint blocks in the Sierra de Atapuerca area (42²0'45.7 "N 3³3'44.7 "W) (Navazo, 2006) (Navazo et al., 2008) and Cretaceous material near Prado Vargas, in the Basque-Cantabrian basin (4302'00.7 "N 3³9'52.6 "W) (Navazo et al., 2005; Navazo \& Díez, 2008; Vallejo et al., 2017).

A set of items was knapped to shape similar technological features to those found at the sites using 10 Neogene flint and 10 Cretaceous flint pieces selected on the basis of the quality of the flint (elasticity, gra- in, hardness) and the morphological similarities of the material to the archaeological items (Figure 3). Flakes were mainly produced, along with two sidescrapers and three denticulate tools, following the pattern observed at both archaeological sites.

The items were analysed technologically on the basis of the Analytic Logical System (Carbonell \& Rodríguez, 2002) to understand their ergonomics. This analysis facilitated comprehension of their morphology and also the choice of zones with the greatest usage potential for later use in the experimental program.

\subsection{Usage Protocol}

An experiment sought to replicate presumed everyday activities of Neanderthal groups. Existing information about available raw material and material remains of activities preserved in the archaeological record was collated. The replicated activities involved the processing of meat (defleshing and dismembering), hides (scraping fresh skin), wood (cutting and scraping fresh material) and bones (periosteum scraping and defleshing on fresh material).

The experiments have been founded on the accessible data on Neanderthals and its economy based on acquisition of resources. Skinning, defleshing and dismembering (meat processing) was done on both fore and hind limbs of roe deer (Capreolus capreolus),
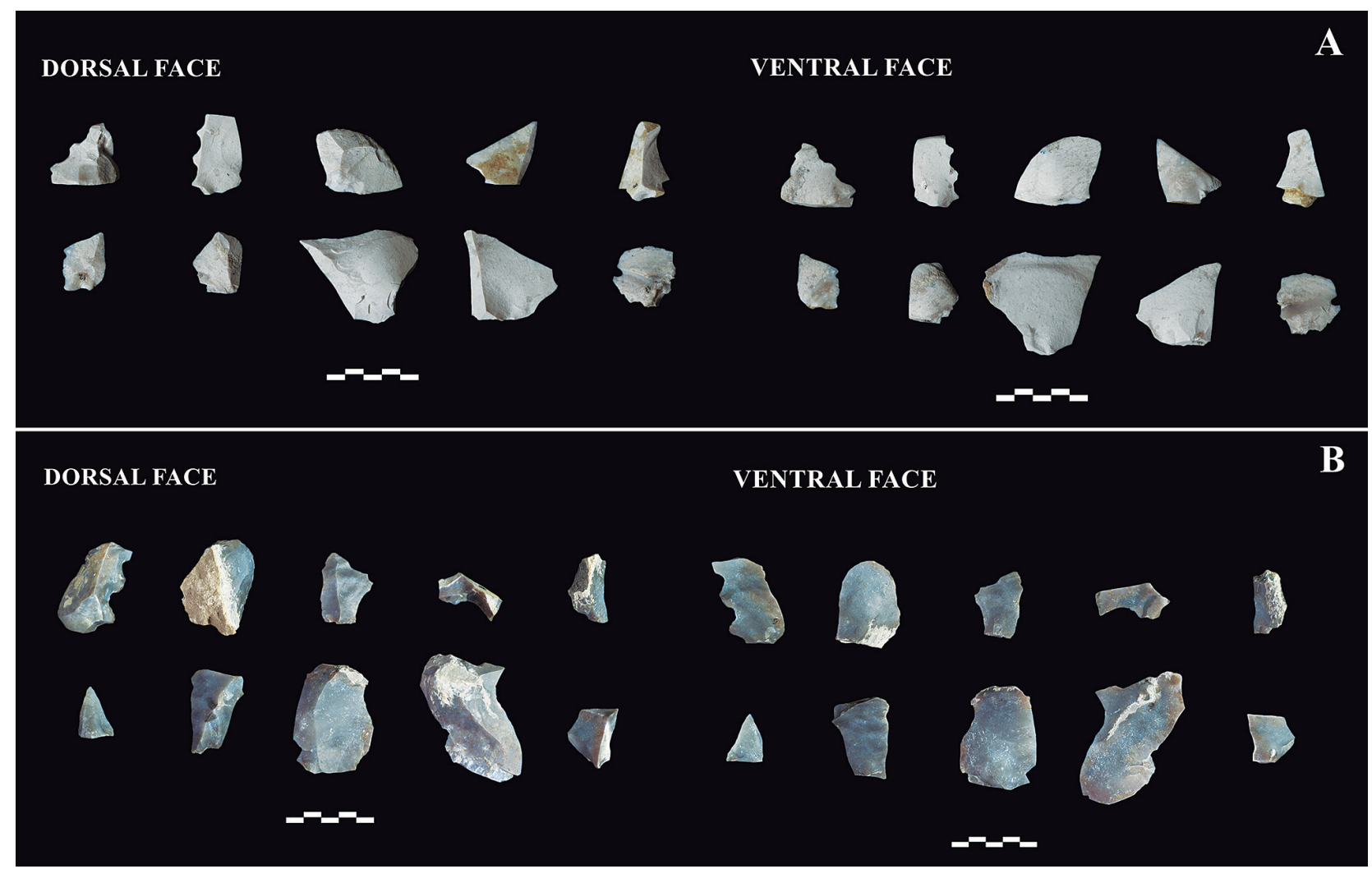

Fig.3. Experimental items: A) Neogene flint. B) Cretaceous flint. / Piezas experimentales: A) sílex neógeno. B) sílex cretácico. 
present in the Prado Vargas record. Roe deer long bones were also used for bone scraping. Bos primigenius taurus limbs were used for work on hides, despite its absence from the Fuente Mudarra record, as the authors considered the species to be representative due to the frequent presence of Bos/Bison in the studied chronology, especially at sites in the Sierra de Atapuerca such as Galería de las Estatuas (Arsuaga et al., 2017). Two wood species, Quercus robur and the softer Ulmus minor, were chosen on the basis of actualism. The material was collected in the vicinity of Prado Vargas.

The experimental programme combined replicative and analytic models (Cueto, 2012) because the aim was to replicate the complete activities, taking into account the type of actions performed separately, and equalizing, for example, the usage time and the raw material whenever possible. This experimental procedure helped to understand how the tool was used, and also to build a reference collection for subsequent use in contrasts with the archaeological material.

\subsection{Cleaning}

The experimental items were left for 15' in an ultrasound tank with a solution of distilled water and low non-ammonium soap as per Márquez (1998). During the microscopic analysis, they were also treated with gasoline due to its high grease solvent power in order to remove any possible fat remaining from contact with the tool. This grease-removal step prevented the manual handing of the items from masking use wear-traces (Martín Lerma, 2015).

\subsection{Microscope Observation}

Finally, the items were analysed under a binocular microscope for preliminary identification and then with a monitored Olympus LEXT OLS3100 confocal microscope at the CENIEH laboratory for higher magnification.

The Keeley Method is essentially appropriate to establish the location and main characteristics of the use wear traces (Faulks et al, 2011), while for more specific cases we have increased the number of magnification.

Laser scanning confocal microscopes (LSCM) permit non-destructive analysis. They can record several scanned images at different heights, which are then superimposed to generate a 3D image (Evans \& Donahue, 2008). This microscope is based on epifluorescence (Claxton et al., 2006). It produces a sharp image by excluding much of the light that is not from the specimen's focal plane (Samwogere \& Reeks, 2005). The molecules of the specimen are excited through incidental light, in this case a higher-intensity laser. The incidental light passes through a pinhole and hits a dichromatic mirror, which redirects it towards the sample. The molecules are excited and their wavelength changes, enabling it on its "return" to pass through the lens, the dichromatic mirror (Samwogere \& Reeks, 2005) and then through a final pinhole to the photomultiplier, which creates an image of the specimen and acquires 3D information. However, the analysis was conducted almost entirely based on the use of $2 \mathrm{D}$ image produced in real time by the microscope using a magnification between $50 x$ and 200x.

In the traceological analysis, the following independent variables were taken into account: raw material, worked material, time, movement and angle of action. The dependent variables were: edge-scarring, striations, polishing and edge-rounding (González \& Ibáñez, 1994; Laborda, 2010).

\section{RESULTS}

The results of the experimental processing of flesh, bone, hides and wood are summarised below.

\subsection{Flesh Processing. Experimentation and Results}

Three pieces of each type of flint were used in the six flesh-working experiments. Capreolus capreolus carcasses were skinned and butchered, deliberately executing unidirectional longitudinal movements. The time spent on each action was roughly one hour, given that the team was more interested in fully completing the activity than the time spent on it. The angle of the piece varied between acute and straight, depending on its manageability for the user and the ergonomics of the tool (Table 1).

On the Neogene flint tools, microscopic inspection revealed traces of contact with flesh, albeit with very slight development, and contact (unintentional) with bone, since during actions such as butchering, the tool was used on flesh, ligaments and also bone, in addition to hide during skinning. Polishing was therefore generally undifferentiated (Martín, 2005) with some specific zones that were smoother, sharp and better defined, with intense edge-rounding and some isolated scar marks.

The same action using different material such as Cretaceous flint generated more cases of linear edge-scarring (mostly semicircular), some of them overlapping (Figure 4A). Polishing was not widespread, but was more appreciable than on the Neogene flint tools, with a rough aspect and an undefined perimeter (Figure $4 \mathrm{~B})$. Edge-scarring was not intense, with the exception of Item 40 , where it was more noticeable.

\subsection{Bone Processing. Experimentation and Results}

Bone processing focused on scraping fresh bone periosteum. Four pieces of flint were used to scrape the Capreolus limbs. In the diaphysis scraping experiment, two Neogene (Items 2 and 8, Table 1) and two Cretaceous (Items 30 and 32, Table 1) tools were used, along with one of each type on the epiphysis (Item 15, 


\begin{tabular}{|c|c|c|c|c|c|c|c|}
\hline Items & Flint type & Material & Activity & Movement & Direction & Angle & Time (min.) \\
\hline 7 & Neogene & Flesh & Processing & Longitudinal & Unidirectional & Straight/acute & 80 \\
\hline 12 & Neogene & Flesh & Processing & Longitudinal & Unidirectional & Straight/acute & 50 \\
\hline 17 & Neogene & Flesh & Processing & Longitudinal & Unidirectional & Acute & 60 \\
\hline 28 & Cretaceous & Flesh & Processing & Longitudinal & Unidirectional & Acute/straight & 59 \\
\hline 35 & Cretaceous & Flesh & Processing & Longitudinal & Unidirectional & Acute & 50 \\
\hline 40 & Cretaceous & Flesh & Processing & Longitudinal & Unidirectional & Acute & 73 \\
\hline 2 & Neogene & Fresh bone & Scraping-diaphysis & Transversal & Unidirectional & Straight/acute & 60 \\
\hline 8 & Neogene & Fresh bone & Scraping-diaphysis & Transversal & Unidirectional & Acute & 60 \\
\hline 15 & Neogene & Fresh bone & Scraping-diaphysis & Transversal & Unidirectional & Acute/straight & 60 \\
\hline 30 & Cretaceous & Fresh bone & Scraping-diaphysis & Transversal & Unidirectional & Straight & 60 \\
\hline 32 & Cretaceous & Fresh bone & Scraping-diaphysis & Transversal & Unidirectional & Very acute & 60 \\
\hline 37 & Cretaceous & Fresh bone & Scraping-diaphysis & Transversal & Unidirectional & Acute/straight & 60 \\
\hline 4 & Neogene & Fresh hide & Scraping & Transversal & Unidirectional & Straight & 60 \\
\hline 16 & Neogene & Fresh hide & Scraping & Transversal & Unidirectional & Acute/straight & 60 \\
\hline 26 & Cretaceous & Fresh hide & Scraping & Transversal & Unidirectional & Straight & 60 \\
\hline 36 & Cretaceous & Fresh hide & Scraping & Transversal & Unidirectional & Acute/straight & 60 \\
\hline 1 & Neogene & Wood/Oak & Scraping & Transversal & Unidirectional & Acute/straight & 60 \\
\hline 14 & Neogene & Wood/Oak & Sawing & Longitudinal & Bidirectional & Acute & 69 \\
\hline 24 & Cretaceous & Wood/Elm & Scraping & Transversal & Unidirectional & Acute & 60 \\
\hline 38 & Cretaceous & Wood/Elm & Sawing & Longitudinal & Bidirectional & Straight & 58 \\
\hline
\end{tabular}

Tabla 1: List of variables recorded during the experiment for both flint types (Neogene, from Fuente Mudarra, and Cretaceous, from Prado Vargas). / Lista de variables recogidas en el experimento para ambos sílex (Neógeno, proveniente de Fuente Mudarra, y cretácico, de Prado Vargas).

Neogene flint, and Item 37 Cretaceous flint, Table 1), given that the movement was less continuous and fluid. Unidirectional transversal movements were executed in all cases for exactly one hour. The working angle varied according to the experimenter's requirements.

Although this experiment involved bone scraping, flesh, fat and periosteum was found on the tool surface, reflecting the matter it had come into contact with. Once again, the Fuente Mudarra Neogene flint showed little development of polishing in Item 2 and Item 15 (Table 1) (the distal part broke during the process), while Item 8 showed a polished strip of hard material (Figure 4C) with a smooth, compact topography and well-defined edges.

Curiously, Prado Vargas Cretaceous flint did not exhibit any development of polished hard material, while it had more scar marks, although this was not widespread (Figure 4D). It also showed a few signs of polishing associated with contact with flesh.

\subsection{Hide Processing. Experimentation and Results}

Only fresh hide was scraped, with no abrasion on the Bos primigenius taurus remains. Once again, the movements were transversal and unidirectional. Work ended after one hour (Table 1). The varying working angle mainly depended on the angle of the tool blade.

Two pieces of Neogene flint were used (Items 4 and 16 , see Table 1), only one of which generated determi- ning traces. A bright polished strip was found parallel to the edge, along with intense edge-rounding, but neither edge-scars nor striations were detected.

Similarly, on the Cretaceous flint, intense edge-rounding and a bright polish along the strip parallel to the edge of the tool were found (Figure 4E, 4F).

\subsection{Wood Processing. Experimentation and Results}

Experimentation on wood was divided between one lithic tool of each flint type for sawing and another two for scraping to thin the object. Neogene flint (Items 1 and 14, Table 1) were used on oak and Cretaceous flint (Items 24 and 38, Table 1) was used on elm. Both wood items were fresh and had a similar hardness.

Two denticulates, one of each type of flint, were used for scraping, and two rough-edged flakes were used for sawing. The Neogene flint tool used for scraping oak evidenced polishing with an irregular topography, particularly in the top zones, and average edge-scarring. The tool used to saw oak was polished on both sides, with an undulating tendency, visible in the top zones, and it had an irregular topography (Figure 4G and 4H).

Cretaceous tools were used to work the elm wood. The denticulate used as a scraper had indeterminate polishing and edge-scars, while the flake used for sawing showed little development of polishing, but intense edge-scarring. 


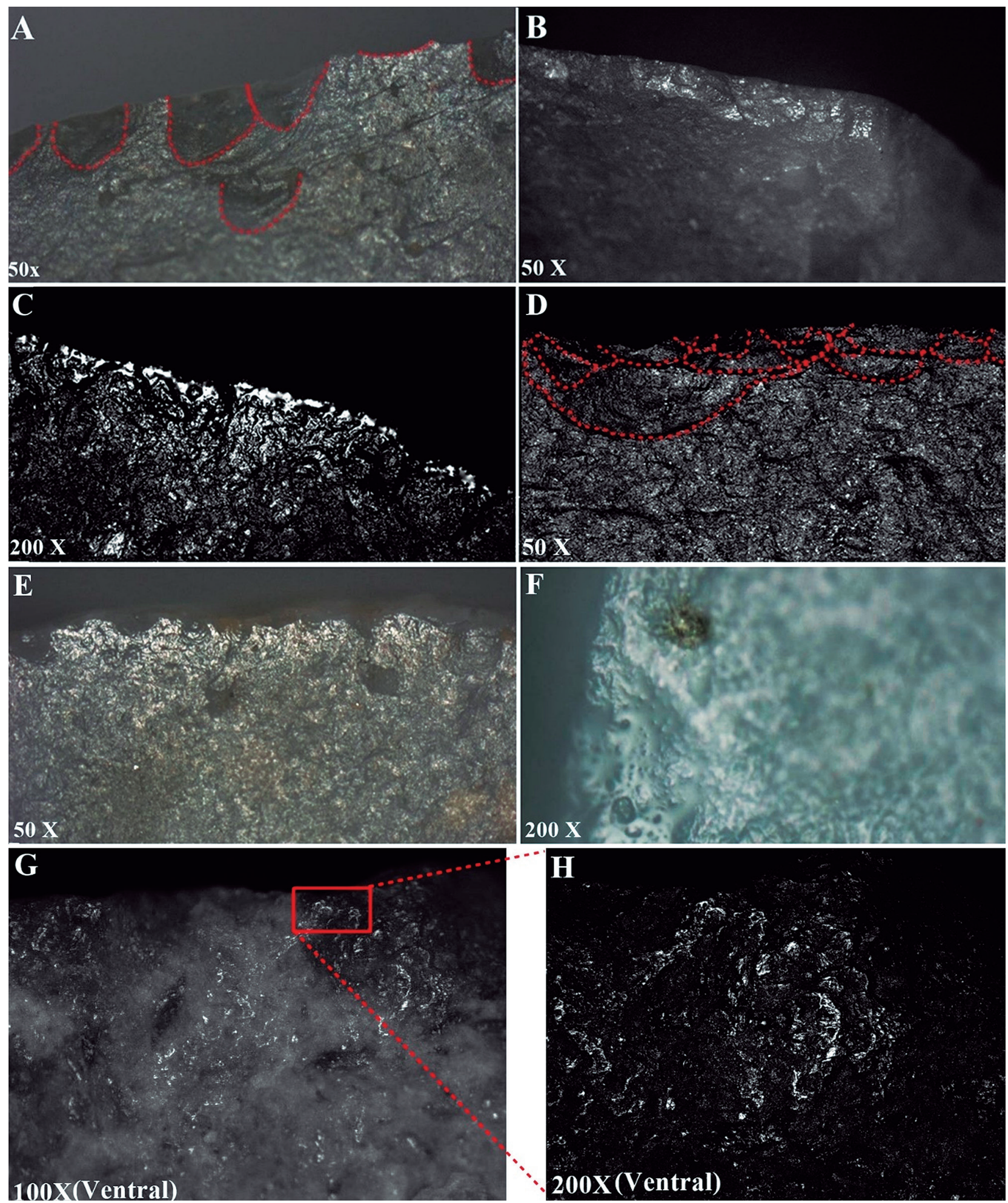

Fig.4. A) Item 28 used for procesing flesh, edge-scarring. B) Item 40 used for procesing flesh, intense edge-rounding and edge-scarring. C) Item 8 used for scrapping bone, polished edge. D) Item 37 used for scrapping bone, semicircular overlapping edge-scarring. E) Item 26 used for scraping fresh hide, polishing \& edge rounding F) Item 26 used for scraping fresh hide, polishing detail. G) Item 14 used for biderctional cut on wood, wood polishing. H) Item 14 used for biderctional cut on wood, polishing detail. / A) Pieza 28, utilizada para el procesamiento cárnico, detalle de desconchados. B) Herramienta 40, usada para el procesamiento cárnico, detalle de un intenso redondeamiento y de desconchados. C) Pieza 8, usada para raspado de hueso, detalle del pulimento en el filo. D) Herramienta 37, usada para raspado de hueso, detalle de desconchados superpuestos y semicirculares. E) Pieza 26, usada para raspado de piel fresca, detalle de pulimento y redondeamiento. F) Herramienta 26 usada para raspar piel fresca, detalle de pulimento. G) Pieza 14, usada para serrado (Bidireccional) de madera, detalle del pulimento. H) Pieza 14, usada para serrar madera (Bidireccional), detalle de pulimento. 


\section{DISCUSSION}

\subsection{Experimental Tools}

The Fuente Mudarra Neogene flint specimens created for the experimentation and employed in the fresh flesh processing experiment (Items 7, 12 and 17) exhibited homogeneous diagnostic features. Polishing resulting from work with soft material was not intense or even non-existent, as expected from this type of action, and was ultimately defined as indeterminate. Only the tool used for 80 minutes (Item 7, see Table 1) showed the characteristic micropolish produced by work on flesh. The small area of these features was probably influenced by the difficulty of generating use-wear traces on such a soft material, even when the item was used for a longer time. In contrast, these tools showed clear evidence of polish from contact with hard material, albeit in small, highly focalised zones, related to unintentional contact with bone, which an experienced user might not produce in such a large amount, as well as incidence in zones where there was contact with the bone during butchering and tendon cutting.

A similar number of scar marks (few) linked to contact with hard material (bone) were found on all Neogene flint items. Somewhat intense edge-rounding was also present in all items, suggesting that this type of butchering dulls flint tool edges. Nevertheless, conclusions about this edge-rounding must be approached with caution, since every type of activity causes a greater or lesser amount of edge-rounding (Gutiérrez, 1990).

More scar marks were found on the Cretaceous flint tools (Items 28, 35 and 40) used for fresh meat butchery than the Neogene tools. However, the edge-scars varied, depending not only on the material employed but also on the force exerted, the position, and the type of movement (González \& Ibáñez, 1994). The characteristic brightness of this type of flint makes it difficult to compare it with the slight polishing of soft material, as in this case, since they have similar characteristics, observed in the microscopic examination prior to use. In addition, there was little polishing due to the above-mentioned minor friction in work on soft materials, and the flexibility and softness of the material causes less resistance on the worked object (Laborda, 2010). Nevertheless, more polished areas were found than on the Neogene items. There was less edge-scarring in this type of flint, with the exception of Item 40 (Figure 4B).

The tools used for bone processing (Items 2, 8 and 15 on Neogene flint, Items 30, 32 and 37 on Cretaceous flint, see Table 1) did not perform as expected, with a high- intensity alteration to the topography of the flint during work on this material. All tools were used on fresh bone. After using the tools for an hour, the polish on both types of flint was not particularly noticeable, with the exception of one piece of Neogene flint (Figure 4C), while there were several scar marks on the Cretaceous tools. They showed scarcely definable or generic polishing. Even the items with more polishing did not clearly corres- pond to the expected characteristics of polishing in bone processing. This may have been due to the flesh removed from the bone, which would have helped to generate a more diffuse morphology, and the lesser contact with the bone after the periosteum was removed. Once again, there were more edge-scarring on the Cretaceous flint items.

The marks produced by hide scraping were similar in both types of flint, Neogene flint Items 5 and 16 and Cretaceous flint Items 26 and 36 (Table 1). Polishing was not found to be widespread, although it was differentiable in the two cases. The processed hides were fresh, a material which does not generate polishing as quickly as dry hides (Laborda, 2010). Friction was constant during the scraping movement, and polishing and scar marks were produced directly (Martín, 2015). The soft nature of the hide ensured that contact was maintained with all areas of the tool edge, reached into the lower topographic zones due to its suppleness. Nether striations nor scar marks, more characteristic of the use of abrasive material, were found on either of the flint items, while edge-rounding of the tools occurred, along with the characteristic bright polishing effect caused in this type of work.

Wood processing involves highly variable degrees of hardness between species (Cordero, 2009). Clear signs of polishing are generally observed in the upper zones of tools, which are characteristically quite bright and have a soft, rounded texture (Gutiérrez, 1991). Several normally stepped cases of edge-scarring are generated, which remove a considerable part of the polishing that occurs (Laborda, 2010). Edge-scarring and slight edge-rounding is also found, although in this respect the hardness of the worked plant material must be taken into account.

In the experimental Neogene flint tools, used for both scraping and sawing freshly cut oak (Items 1 and 14, Table 1), polishing was noted in isolated areas in the upper zones of the topography. Both showed similar characteristics. The two items differed in the distribution of the polishing effect, found in a strip running parallel to the edge in the case of scraping and in undulating sections in the case of sawing, penetrating deeper into the piece, and with higher areas with a smoother rather than irregular topography. This may be defined as more developed polishing at a more advanced stage.

While the marks left on the Neogene flint were homogeneous, the Prado Vargas Cretaceous flint showed differences (Items 24 and 38). In Item 24, used to scrape fresh elm wood, the polishing was at an initial stage, hindering its diagnosis. It also had several edge-scarring. The tool used for sawing fresh wood showed one zone with initial stages of polishing and another from the end, which was clearer. It was also intensely rounded.

\subsection{Comparative Archaeological Studies}

Previous papers have presented a brief traceological analysis of seven tools from the Fuente Mudarra site, four of which presented use-wear traces (Figure 

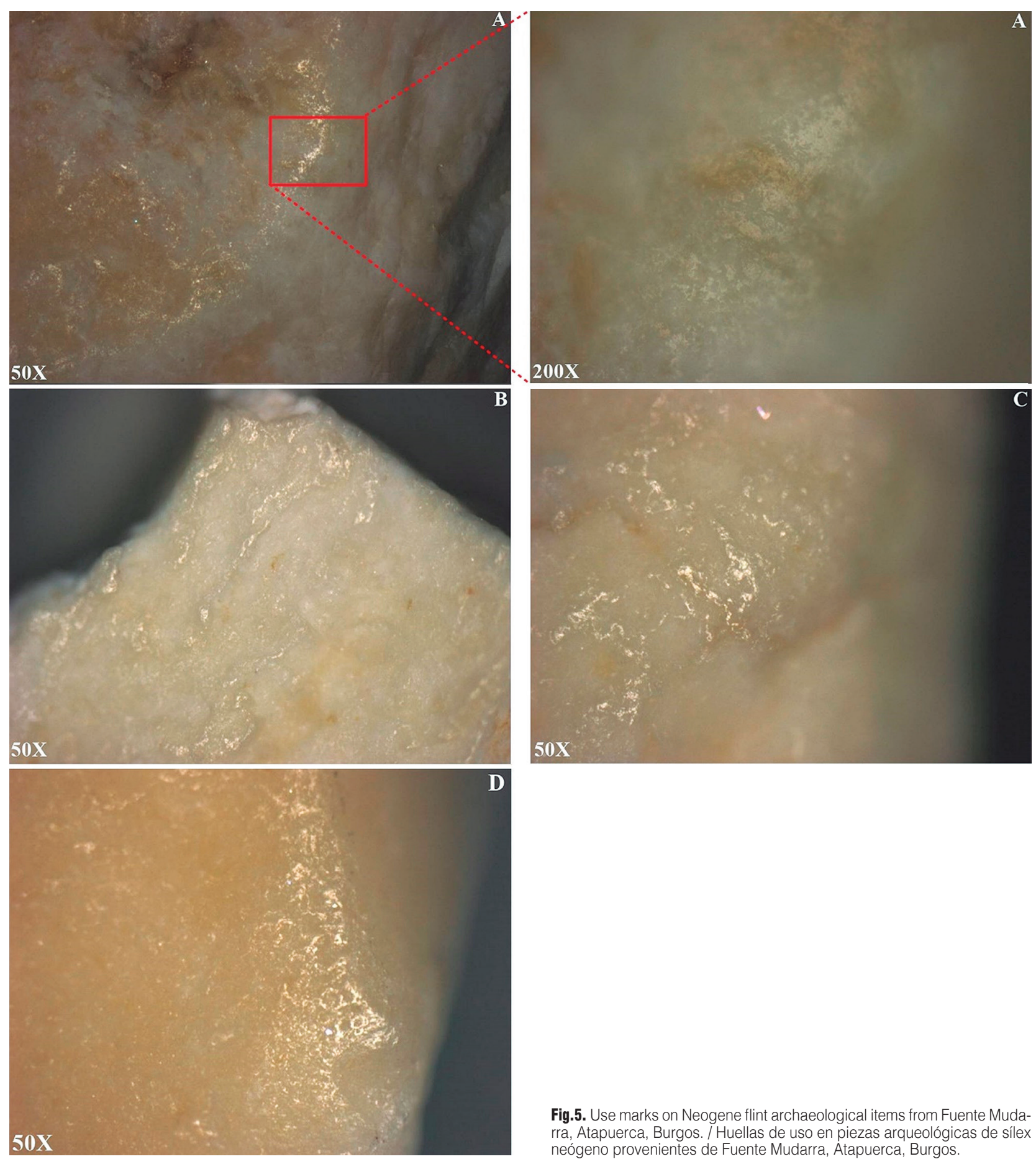

Fig.5. Use marks on Neogene flint archaeological items from Fuente Mudarra, Atapuerca, Burgos. / Huellas de uso en piezas arqueológicas de sílex neógeno provenientes de Fuente Mudarra, Atapuerca, Burgos.

5) (Santamaría \& Navazo, 2016) and nine from Prado Vargas, eight of which had such traces (Figure 5) (Santamaría et al. 2016).

One of the Neogene flint items from the Fuente Mudarra site in the Atapuerca area was found to have been used for hide scraping (Figure 5A), two were used for wood scraping (Figure 5B, 5C) and one was used on soft or semi-soft material (Figure 5D) (Santamaría \& Navazo, 2016).

Amongst the archaeological material in Cretaceous flint from the Prado Vargas site, four tools were found to have been used for meat processing (Figure 6A, 6C, $6 \mathrm{E}, 6 \mathrm{H}$ ), two for hide scraping (Figure 6B and 6F) and two for wood processing (Figure 6D, 6G) (Santamaría et al., 2016).

It is important to note that microscope observation of this flint prior to its use found that its intrinsic bright- 

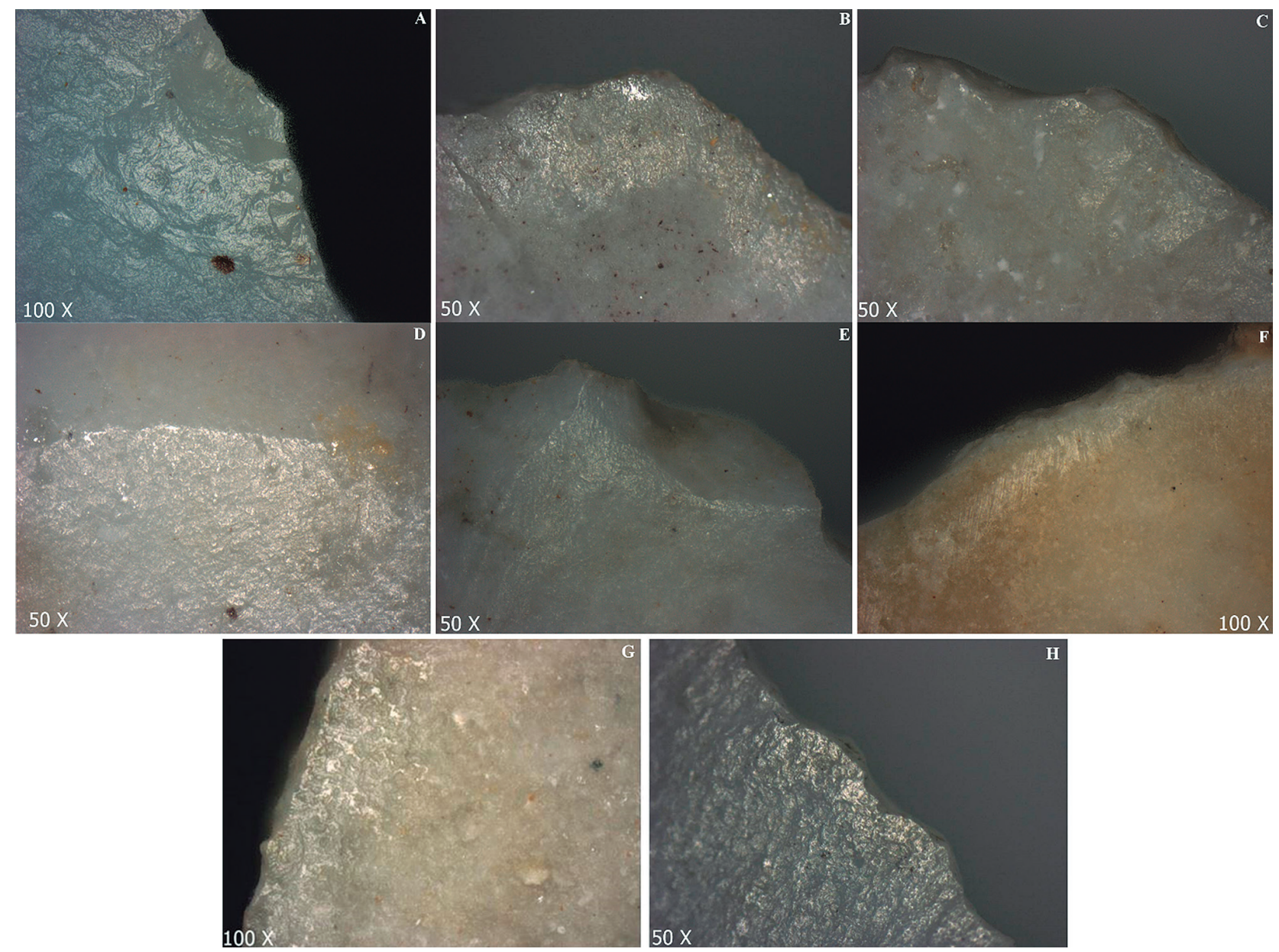

Fig.6. Use marks on Cretaceous flint archaeological items from Prado Vargas, Cornejo, Burgos. / Huellas de uso en piezas arqueológicas de sílex cretácico, provenientes de Prado Vargas, Cornejo, Burgos.

ness can be confused with polished soft material. Results in this aspect must therefore be approached with caution with respect to archaeological specimens which lack prior references.

The marks found on these tools, especially those from Fuente Mudarra, seemed to be at a more advanced stage of development than those on the experimental tools. Several striations associated with use were found on one item from the Prado Vargas site, but they could not be compared due to the absence of similar lines on the experimental tools. The item seems to have been related to work on hide, making an experiment with abrasives necessary to fully comprehend its use.

Undeveloped polishing was found with a similar aspect in all the material. This variable (polishing) tends not to exhibit defining qualities from the initial contact, and instead it tends to develop gradually (Laborda, 2010). Vaughan (1985) suggests three stages in the generation of polishing. The first one lacks defining features on the tool, the intermediate one has a 'pitted' aspect, and the final one is distinguishable (Martín, 2015). This implies that in many uncontrolled cases, the mate- rial is not distinguishable and episodes of polishing can overlap if the tool was not used with sufficient intensity (González \& Ibáñez, 1994). This obviously makes more difficult to define material from the archaeological record than experimental material. This case of polishing may therefore indicate an early stage of work, hindering a clear identification in some cases.

\section{CONCLUSIONS}

First of all, the brief experimental and archaeological sample and the results do not allow us to extrapolate all the information that we would like to the sites. This requires a more complete study proposed in the near future. Even so, some results have been observed.

Being this a preliminary study, patterns of use-wear traces were found on archaeological tools similar to the experimental ones, permitting the identification of the work performed using the archaeological items.

Cretaceous flint seemed to be more susceptible to edge-scarring, i.e., fragmentation. However, this depended not only on the qualities of the flint but also other 
variables such as the edge angle, the force applied and the stroke angle.

Neogene flint seemed to be more prone to the characteristic polishing of hard material, while Cretaceous flint is more responsive to soft material. This could be related to the different topography of each flint and their type of grain. Coarser-grained Neogene flint had rougher areas, with greater differences between the upper and lower areas of the surface, while finer-grained Cretaceous flint presented more uniform development. The characteristics of the latter flint bear an intrinsic resemblance to this type of polishing, and the brightness of the piece itself can be confused with the polishing of meat material.

Several of the archaeological items showed similar features to those generated on the experimental tools. The authors were able to discern work on wood and hides at the Fuente Mudarra site, while at Prado Vargas, meat processing was also detected, along with work on the same two materials.

In the experimental record, many traces were identified by high-power magnification. In the archaeological material, however, traces were more clearly identifiable at lower magnifications, and higher magnifications were only necessary for some details. This implies less development of the traces in the experimental tools, which were used for about an hour. In comparison with the experimental tools, and given that the protocol was applied using the same type of flint as the material found at the site, the archaeological items showed a greater development of use-wear traces, suggesting that they were used either more intensely or over a longer period.

As seen in the experimental section, different morphologies are ergonomically adaptable to all activities, although the edge angle has a greater influence on the quality of the work and the ease with which it is done. The variations in the present morphotypes were thus not influenced by the functional use of the tools. Different materials could be transformed by work with more than one morphology (e.g., flakes used for tanning, sidescrapers for wood). The uses were more influenced by the type of work, i.e., the direction of the stroke (transversal or longitudinal-cut or scraped) and less so by the worked material. This suggests a considerable versatility in the use of tools, without considering a specific typology.

There was probably greater flexibility or ability to adapt the use of tools, according to the morphologies, to the needs of these populations, bearing in mind the resources and the subsistence models of these groups: the amount of raw material available, their cultural tradition and the potential of each tool played a fundamental role.

\section{ACKNOWLEDGEMENTS}

This study is supported by the Local Government of la Merindad de Sotoscueva and Cornejo This paper is part of a Project financed by the Regional Government of
Castilla y León and the Ministry of Culture and Tourism, Directorate General of Cultural Heritage: "Intervención arqueológica en la Cueva de Prado Vargas, en Cornejo (Merindad de Sotoscueva, Burgos)" (C02W06). This work was done with the help of the CENIEH laboratory, which allowed the authors to use the necessary equipment, the University of Burgos, which provided work space, and CRAS, which supplied the necessary material to conduct the experiment, and Thanks also go to Marcos Terradillos, responsible for knapping the items, and Ignacio Martín Lerma for his help in the analysis. Finally, thanks also to Rodrigo Alonso and the rest of the team, Marta, Héctor, Pedro and Sandra for their support for this work.

\section{REFERENCES}

Alonso-García, P., Navazo, M., Blasco, R., 2020. Use and selection of bone fragments in the north of the Iberian Peninsula during the Middle Palaeolithic: bone retouchers from level 4 of Prado Vargas (Burgos, Spain). Archaeological and Anthropological Sciences, 12(9), 1-12. https://doi.org/10.1007/s12520020-01097-z.

Arceredillo, D., 2010. Los macromamíferos del yacimiento del Pleistoceno Superior de Prado Vargas (Burgos, España). XXVI Jornadas de la Sociedad Española de Paleontología. III Congreso Ibérico de Paleontología.

Arsuaga, J.L., Gómez-Olivencia, A., Sala, N., Martínez-Pillado, V., Pablos, A., Bonmatí, A., Pantoja-Pérez, A., Lira-Garrido, J., Alcázar de Velasco, A., Ortega, A.I., Cuenca-Bescós, G., García, N., Aranburu, A., Ruiz-Zapata, B., Gil-García, M.J., Rodríguez-Álvarez, X.P., Ollé, A., Mosquera, M., 2017. Evidence of paleoecological changes and Mousterian occupations at the Galería de las Estatuas site, Sierra de Atapuerca, northern Iberian plateau, Spain. Quaternary Research 88, 345-367.

Bagolini, B., 1968. Richerche sulle dimensioni dei manuffati litici preistorici non ritoccati. Annali dell'Universitá de Ferrara I- 10, 195-218.

Binford, L.R.. Binford, S.R., 1966. A preliminary analysis of functional variability in the Musterian Levallois facies. American Anthopologist 68(2), 238-295.

Bordes, F., 1961. Typologie du Paléolithique Ancien et Moyen. Centre National de la Recherche Scientifique, Paris.

Calvo, M., 2002. Útiles prehistóricos. Forma, función y uso. Ariel, Barcelona.

Claxton, N. S., Fellers, T. J., Davidson, M. W., 2006. Microscopy, Confocal. Encyclopedia of Medical Devices and Instrumentation

Cordero, R., 2009. Tras la huella de los cazadores recolectores en la tradición de bosques templados. Universidad de Chile. $\mathrm{PhD}$ thesis.

Cueto, M., 2012. Manufactura, utilización y análisis de huellas de uso sobre artefactos líticos tallados en rocas silíceas de la meseta central de Santa Cruz. Diseño y desarrollo del programa experimental. Entre Pasados y Presentes III. Estudios Contemporáneos en Ciencias Antropológicas, 762-781.

De la Fuente Juez, H, García Domínguez, S, Navazo Ruiz, M, Blasco López, R., 2020. Tafonomía del registro fósil de macromamíferos del Pleistoceno Superior en el nivel 4 de la Cueva de Prado Vargas (Cornejo, Burgos, España). Munibe Antropologia- Arkeologia, 71. https://doi.org/10.21630/maa.2020.71.02 
Dibble, H., 1987. The interpretation of the Middle Paleolithic Scraper Morphology. American Antiquity, 52.

Dibble, H., Rolland, N., 1990. Beyond the Bordes-Binford Debate: A new synthesis of factos underlying assemblage variability in the Middle Palaeolithic of Western Europe. In: Dibble, $\mathrm{H}$., Mellars, P. (Eds.) New Perspectives of Human Adaptation and Behaviour in the Middle Palaeolithic. University of Pennsylvania Press.

Evans, A.A., Donahue, R.E., 2008. Laser scanning confocal microscopy: a potential technique for the study of lithic microwear. Journal of Archaeological Science 35, 2223-2230.

Faulks, N. R., Kimball, L. R., Hidjrati, N., Coffey, T. S., 2011. Atomic Force Microscopy of Microwear Traces on Mousterian Tools From Myshtylagty Lagat (Weasel Cave), Russia. Scanning 33, 304-315.

González, J.E., Ibañez, J.J., 1994. Metodología de análisis funcional de instrumentos tallados en sílex. Cuadernos de Arqueología 14. Universidad de Deusto.

Gutiérrez Sáez, C., 1990. Introducción a las huellas de uso: los resultados de la experimentación. Espacio, Tiempo y Forma. Prehistoria y Arqueología 3, 15-53.

Gutiérrez, C., 1991. Notas en torno a la identificación en las huellas de uso: La cuestion del pulimento. Cuadernos de Prehistoria y Arqueología 18, 21-33

Kuhn, S.L., 1991. "Unpacking" Reduction: Lithic raw material economy in the Mousterian of west-central Italy. Journal of Anthropological Archaeology 10.

Laborda Martínez, M.A., 2010. Análisis de huellas de uso. Su aplicación al estudio de la funcionalidad del instrumental lítico de la Cueva de Zatoya (Navarra). PhD thesis. Navarra University, Pamplona.

Lemorini, C., Bourguignon, L., Zupancich, A., Gopher, A., Barkai, R., 2016. A scraper's life history: Morpho-techno-functional and use-wear analysis of Quina and demi-Quina scrapers from Qesem Cave, Israel. Quaternary International 398, 86-93.

Márquez Mora, B., 1998. El nivel TG10 de Galería (Atapuerca, Burgos). Aplicación de un programa experimental para el estudio traceológico de conjuntos líticos del Pleistoceno medio. Complutum 9, 9-26.

Martín Lerma, I., 2008. Análisis microscópico de la Industria lítica: la traceología. Panta Rei III. $2^{\circ}$ época, 15-25

Martín Lerma, I., 2015. Funcionalidad de la industria lítica magdaleniense del interior peninsular: la Peña de Estebanvela (AyIlón, Segovia). PhD thesis.

Mellars, P.A., 1992. Technological change in the Mousterian of the southwest France. In Dibble and Mellars (Eds.) The Middle Paleolithic: Adaptation, Behaviour and variability. Philadelphia. The University Museum. University of Pennsylvania, 72, 29-43.

Monnier, G., Missal, K., 2014. Another Mousterian Debate? Bordian facies, chaîne opératoire technocomplexes, and patterns of lithic variability in the western European Middle and Upper Pleistocene. Quaternary International 350, 59-83.

Navazo, M., 2006. Sociedades cazadoras-recolectoras en la Sierra de Atapuerca durante el Paleolítico Medio: patrones de asentamiento y estrategias de movilidad. PhD thesis. Burgos University.

Navazo, M. Carbonell, E., 2014. Neanderthal settlement patterns during MIS 4-3 in Sierra de Atapuerca (Burgos, Spain). Quaternary International 331, 267-277.
Navazo, M., Colina, A., Domínguez, S., Benito-Calvo, A., 2008. Caracterización y gestión de materias primas en los asentamientos al aire libre de la Sierra de Atapuerca (Burgos). Actas del VII Congreso Ibérico de Arqueometría, 346-359.

Navazo, M., Díez, J.C., 2008. Prado Vargas y la variabilidad tecnológica a finales del Paleolítico Medio en la meseta norte. Treballs d'Arqueologia 14, 121-139.

Navazo, M., Díez, J.C., Torres, T., Colina, A., Ortiz, J.E., 2005. La Cueva de Prado Vargas: Un yacimiento del Paleolítico Medio en el Sur de la Cordillera Cantábrica 20, 151-166.

Rolland, N., 1990. Middle Palaeolithic socio-economics formations in Western Eurasia: an exploratory survey. In: Mellars, P. (Ed.), The Human Revolution. University Press. Edinburgh.

Santamaría, C., Luengo, S. M., Navazo, M., Benito-Calvo, A., Martín, I., 2016. Aproximación metodológica y primeros resultados sobre huellas de uso en herramientas de sílex del yacimiento musteriense de Prado Vargas (Cornejo, Burgos, España), a través de microscopio confocal. DigitAR 3, 15-22.

Santamaría, M., Navazo, M., 2016. Fuente Mudarra: la industria lítica de un asentamiento musteriense en la Sierra de Atapuerca (Burgos). Arqueología en el valle del Duero: Del Paleolítico a la edad Media 5, 19-34.

Santamaría, M., Navazo, M., Benito-Calvo, A., Alonso, R., López, G. I., Carbonell, E., 2020. Atapuerca Neanderthal landscape at Fuente Mudarra site in Burgos, Spain, during Marine Isotope Stages 5-3. Quaternary Research, 1-22. https:// doi.org/10.1017/qua.2020.65

Samwogerere, D., Weeks, E. R., 2005. Confocal microscopy. Encyclopedia of Biomaterials and Biomedical Engineering, Biomaterials, Biomedical Engineering. Emory University, Atlanta, Georgia, U.S.A

Texier, P., Brugal, J. P., Desclaux, E., Lemorini, C., López Sáez, J. A., Thery, I., Wilson, I., 2003. La Combette (Bonnieux, Vaucluse, France): a Mousterian sequence in the Luberon mountain chain, between the plains of the Durance and Calavon rivers. Preistoria Alpina 39, 77-90.

Torres, T., 1989. Excavación de la Cueva de Prado Vargas, Cornejo (Burgos-España). In: II Reunión del Cuaternario Ibérico, 25-29. Madrid, España.

Vallejo, S., Urtiaga, K., Navazo, M., 2017. Characterization and supply of raw materials in the Neanderthal groups of Prado Vargas Cave (Cornejo, Burgos, Spain). Quaternary International $435,35-48$

Vaughan, P. C., 1985. Use-wear analysis of flaked stone tools. University of Arizona Press, Tucson (Arizona). 
